Gadjah Mada International Journal of Business

September 2004, Vol. 6, No. 3, pp. 383-404

\title{
THE PREPAREDNESS \\ OF THE INDONESIAN GARMENT EXPORTERS IN THE POST-MFA SCENARIO An Analysis from the Survey
}

\author{
Muchsin Shihab \\ Sudhir K. Jain
}

The clothing or garments industry has developed rapidly during the past some decades and has contributed to the economic growth of many nations, both developed and developing countries. This industry has been very much regulated by many bilateral agreements such as Multi Fiber Arrangement (MFA), a quota arrangement made by the importing countries. As MFA (quota regime) comes to an end by 2005 and integrates into the WTO regime, it will bring opportunities to highly competitive and proactive garment exporting countries whereas the challenges will be faced more by the less competitive countries. Issues related to environment and social compliance, technology requirements etc. have been brought into surface by the importing countries, which may worsen the condition. Under the above scenario, it is imperative that certain proactive measures be taken. Thus, the broad objective of this study is to analyze the response of the garment exporters from Indonesia towards the emerging issues related to environmental and social compliance, technology requirements etc.

The present study is a questionnaire-based study. The samples have been selected from the Directories of largest exporters in the country. With reminders and persuasion, the final number of useable responses has been 115 Indonesian garment exporters. Seven factors of the emerging issues were identified by using factor analysis. In addition, factors of competitiveness, and the strategies adopted by the exporters have also been analyzed. The findings show that the overall perceptions of the Indonesia garment exporters indicate that Indonesia is less competitive as compared to other competing countries.

Keywords: clothing; compliance issues; economic; exports; garments; Indonesia; MFA 


\section{Introduction}

The clothing (or garments as often used interchangeably) industry has developed rapidly during the past some decades. This industry is important for the developing as well as developed countries as it contributes significantly to the employment generation and economic growth. During the past several decades, the world textiles and clothing markets have remained quite distorted among the manufactured commodities as they have been regulated by the consecutive international agreements such as Short Term Arrangement (STA), Long Term Arrangement (LTA) and Multi Fiber Arrangement (MFA), which contravene the GATT principles (Yung 1999). All these arrangements were actually intended to protect the domestic industry of the developed countries from external competition (Bull et al. 1993; Debroy 1996; Gapalsamy 1998; Prada 1998). Due to MFA's undesirable features such as discrimination and market distortion (Khanna 1991; Dickerson 1993; Bhattacharya 1999), it was decided to phase out the MFA during the Uruguay Round of GATT Negotiations that concluded in 1994. A period of 10 years has been decided for the complete phase out of the MFA.

The dismantling of the quota regime represents both opportunities and threats (Textile Asia 2000) to garment developing exporting countries. Several researchers have reviewed the literature on the international trade of textiles and garments on the opportunities and the challenges on the abolition of the MFA and the introduction of the WTO's Agreement on Textiles and Clothing (ATC). Apart from a greater access to markets and market transparency, the MFA phase-out seems to be posing more challenges for the developing exporting countries. Some studies have revealed that exports of textiles and clothing are likely to have higher degree of competition leading to pressures on price (Koshy and Jain 1994), increased domestic competition from foreign firms (Chandra 1999; Kathua 2000), reduced emphasis on cost as the sole determinant of competitiveness (Katti and Suber 2000; Birnbaum 2001), quality price match (Koshy 1995 , 1997), and speed (Koshy 1995; Djafri 1999; Anson 2001).

Indonesia's garments industry, one of the largest in the domestic manufacturing sector, has contributed to the economic growth and employment generation of the country. The importance of garment exports to Indonesia during the past decade(s) can be realized by the fact that the share of employment in the garments industry has increased from 6 per cent in 1985 to 10 per cent in 1998 (of the total manufacturing) and that the country's exports increased from US $\$ 592$ million in 1987 to US $\$ 4,734$ million in 2000 or at an average growth rate of about 17 percent. Apart from the benefit of low labor cost, the increase in garment exports from Indonesia has been due to availability of skilled labor (Dennison 1995), government supports through a series of conducive policy (Djafri 1999), and Indonesia's joint venture such as with Kenzo, Arrow, etc. (Dennison 1999). However, the growth rate of garment exports from Indonesia does not reflect its global shares (approximately 2.4 percent) and this has been very small as compared to some other competitors like China, Hong Kong, Italy, USA, and Mexico. Even in the major destination markets, Indonesia' shares of 3.4 percent in US market and 1.92 percent in EU market have been smaller as compared to some other competing countries. The presence of the quota systems has actually 
Shihab \& Jain-The Preparedness of the Indonesian Garment Exporters in...

guaranteed market for Indonesian garment manufacturers. This country benefited from the MFA by having assured quotas in a competitive environment during the early years of production (Djafri 1999). Although, it is too early to forecast, the adverse effect of the MFA phase out has been felt by Indonesia. This country has been facing problems of declining growth of exports since the MFA phase out. Thus, the dismantling of the quota regime poses more challenges than opportunities particularly to Indonesia. Accordingly, this country is forced to undertake drastic restructurization and develop new strategies to retain competitiveness. It may not suffice to rely on the low labor cost advantage alone, if this country wants to enhance or retain its competitiveness. Thus, the main purpose of the present study is to analyze the responses of the garment exporters from Indonesia about their understanding and preparedness to face the emerging challenges in the coming years.

\section{Major Issues Facing the Industry}

As mentioned earlier that the dismantling of MFA poses more challenges to garment developing exporting countries, because the garment importing countries viz. developed countries put pressure on the issues related to environmental and social compliance, technology requirements etc. to exporters. The major issues are discussed below.

\section{Labor Cost Advantage: Thing in the Past}

Labor cost is a predominant issue particularly in garments industry. Many studies have shown that better standing of garments industry in Indonesia has been due to the advantage of cheap labor cost apart from the government support and assured quota (Dennison 1995; Djafri 1999). In 1998, the hourly wage rates in Indonesia was US\$0.16 as compared to US\$0.39 in India, US\$1.34 in Mexico, US\$1.28 in Honduras, US\$0.78 in Thailand, US\$0.76 in Philippines, US\$0.43 in China, US\$0.30 in Bangladesh, US\$0.24 in Pakistan, US\$0.22 in Vietnam, and US\$0.13 in Myanmar (Werner International Consultants 1999). However, this low labor cost as a competitive advantage cannot sustain long. Debroy (1996) and Koshy (1997) have revealed that labor costs do not necessarily lead to price competitiveness or do not seem (Das 2000) at all significant. Higher capital cost (Debroy 1996; Koshy 1997); poor productivity level and timely delivery (Koshy 1997; Das 2000) have rendered this advantage vulnerable. Birbaum (2001) has analyzed the competitive advantage of various exporting countries and concluded that in present scenario the importance of labor costs has declined. Thus, lower labor cost, which had a beneficial effect on the prices, is a thing in the past, because it can be easily imitated by others. In today's competition, garment exporters are faced with the emerging issues, among others, related to environmental and social compliance, (Debroy 1996; IIFT 1997; Mehta 1997; Chandra 1999; Djafri 1999), and technology requirements adopted by importing countries. These all have become and will be the stumbling blocks for the garment exporters in the future.

\section{Buyers' Control: Stressing on the Environmental and Social Compliance}

Nowadays, international buyers are placing importance on the environmental and social compliance issues (code of conduct as they call) such as provision of 
quality of the employees' work-life, safety, healthy working environment, minimum wage standard etc. The basic concept here is to give a sense of security to consumers where they purchase products. The compliance issues implicitly also get interpreted as one of the ways of restricting the imports by developed countries from developing countries. The international standard compliance has been practiced by most of the international garment-brands and is tending to become requirement for exports too. Fernando (2000) has observed that obtaining the international standard compliance certification and its advertising is sufficient as order-winning strategy but it is going to become requirement very shortly. In order to monitor these standards, many well-known brands have undertaken measures such as sending their inspection groups to factories to investigate on working conditions of the factories before placing orders (Panthaki 2001; Tait 2001a).

Although most compliance certification requirements are similar, all importers follow different norms. So if an exporter is making for NIKE, the Gap, Liz Clayborne, and C\&A, for example, then (s)he is likely to have to comply to different codes. Thus there might be some confusion and conflicting requirements (Tait 2001b). Therefore, the prominent apparel producers approached the American Apparel Manufacturers Association (AAMA) to coordinate the industry's role in addressing these issues. This has led to the Worldwide Responsible Apparel Production (WRAP) principles, basic standards that address labor practices, factory conditions, and environmental and customs compliances and business will be transacted only with the units approved by this agency who will also ensure that the units adhere to the principles of WRAP (Clothesline
2001). The EU has also planned to implement a compliance certification like WRAP standard for Textile and Textile Product (TTP) industry (Tanudjaja in Bharattextile.com). Thus, it can be said that the environmental and social compliance issue is one of the issues that are becoming more and more important for the garment exporters for survival in the future and the existence cannot be ignored by the exporters Indonesia.

\section{IT and Automation}

Nowadays, buyers have stressed on the need to adhere to international standards for faster response. Kilduff (2000) and Fralix (2001) have revealed that Information Technology (IT) and automation play a key role in building and shaping the linkage between customers and manufacturers. And the Internet is one of the most exciting developments in technology (Dawson and Kang 2001). Chintakayada (1999) has stated that globally textiles and clothing industry is becoming more and more IT driven. He further mentioned that apparel industry should understand that IT encompasses a range of information at all stages of production chains and to ensure the timely compliance with the customers. It allows us to get high speed, cost reduction, crashing the lead-time, flexibility, wider choices of goods and these will ultimately add value to the business system. Companies would be able to add value and save costs using IT solutions (Mathew 2000). Thus, IT should be used in such a way that it brings effectiveness and efficiency. It should go to total systems, not partially, in the organization, right from market intelligence, product design, and production system to the lowest functions. Thus, investments in information technology are critical in this age. As Wal Mart invested in technology, it not 
Shihab \& Jain-The Preparedness of the Indonesian Garment Exporters in...

only brought the costs down (Stiedtmann 2000), it also lowered prices and expanded the market. Thus, it can be concluded development of IT will determine the future success of textiles and garments business. In addition to IT, the automated manufacturing facility such as CAD/CAM system is also important in the production process in augmenting flexibility in design. This system has opened up new avenues to creativity of designers giving them opportunities to make alterations in design (Fashion and Beyond 2000).

\section{Value Addition Related}

For most marketers, the concept of value added is predicted on the belief that consumers are willing to pay more for higher value added products (Brookes 1988). Manufacturers should offer something unique, unmatched by their low-cost competitors, i.e. products highly valued by their buyers for reasons beyond simply an attractive price to remain competitive (Moon et al. 1997). Buyers nowadays are choosy, knowledgeable and understand the value of the products. Panthaki, (2000b) has observed that the urge to move away from traditional products to those that add value to your products should be of paramount importance. There are certain ways to have value addition such as through branding (Koshy 1999; Sung 2000), production flexibility (Kini 2000; Ellis 2001), and product development and design (KSA Technopak 1999).

\section{Time Value Related}

Marketing starts from understanding consumer behavior. Thus, understanding and reacting out to what the consumer wants is essential. In garments industry, fashion for one product may come in a very short span. (Koshy 1998) has men- tioned that the life span of the products on shelf is disproportionately short i.e. six to eight weeks. He has further mentioned that in garments industry time really matters which in turn will create value. Thus, speed that has led to timeliness of delivery and responsiveness to changing needs has now been a major focus (Singletary and Samuel 1998; Anson 2001). The aware consumer is also impatient and he wants everything right away (Diesback 2000). To minimize the risk of wrong merchandise selection, buyers place their orders closer to the season and that the delivery turnaround times are shrinking. Rather than placing one large order, the buyers are making many smaller orders (Jain 2000). Even Koshy (1997) has stated that value added is value lost if delivery fails to take place in time. Thus, commitment to delivery time, shorter manufacturing time and shorter lead-time seems to be important in today's scenario.

\section{Research Methods}

\section{Questionnaire Design}

The present study is mainly questionnaire-based survey. However, personal interviews and discussions with experts and practitioners have also been carried out. The questionnaire was developed through several stages. Initially, to search for items on current issues effectively, the body of literature and seminars on the concerns, problems and prospects of the phase-out of MFA were reviewed in parallel with the discussion with the experts in this area. Then the questionnaire was developed. To validate the researcher's concepts and perceptions about the variables, which were used in the questionnaire, face validity test was performed. At this stage, discussion with experts, managers of gar- 
ment exporting companies and researchers were held. They were requested to critically examine and modify the variables, which have been designed. This work was intended to strengthen the researcher's judgment about the emerging issues. This was very helpful to the researcher especially for the correction of the language and setting of the content of the questionnaire. Large number of suggestions were incorporated at this stage. Subsequently, the questionnaires were sent to the garment exporters for pre-testing to achieve content validity. The purpose of this pre-testing was to evaluate the clarity and applicability of the questionnaire. Minor modifications were made for the finalization of the questionnaire.

\section{Survey Implementation}

500 garment exporters were selected from the current edition of the Directory of Exporters published by API (Assosiasi Pertekstilan Indonesia), Jakarta. Subsequently 500-survey questionnaires were mailed, and 115 completed responses (i.e. $23 \%$ ) were received. Firms include quota and non-quota exporters. Questionnaires were mailed to the chairmen and managing directors from a wide range of Indonesian garment exporters located in the country. Each mailed-envelope contained a set of questionnaire, covering letter and a postage-paid self-addressed envelope. The covering letter contained the purpose of the survey, confidentiality of the identity of the respondents. A reminder along with another copy of the questionnaire was sent four weeks after the first mail. Second reminder was sent after 6 weeks but without questionnaire.

The questionnaire for the exporters consists of 5 sections. This study only discussed 4 sections viz. section 1,2, 3 and 5. Section one contains the respondent's and organization's particulars which cover the name and position of the respondent, company's name, address, e-mail and website availability, year of establishment, type of the organization, average annual exports, main products for exports, years of experience in garment business, and the recent trend of the garment exports. Section two of the Questionnaire relates to the perceptions of the exporters on factors of competitiveness of the country. There are five factors listed in this measurement namely labor related, infrastructure related, business law related, raw materials related, technology/manufacturing related, and "others." The exporters were asked to indicate their perceptions on a five-point scale about their country's strength on those various variables of factors of competitiveness. Section three pertains to the assessment of the exporters on the level of importance to the garment manufacturing and exports. The exporter respondents were asked to indicate the level of importance they attach to various issues related to garment manufacturing and exports. Factor analysis was used for data reduction and summarization. Section five is based on the strategic choices the respondents and other companies applied during the MFA phase-out (1995 onwards). The exporters were also asked to indicate adoption of strategic choices by them as well as majority of their competitors.

\section{Results and Analysis}

\section{Sample Characteristics}

Table 1 presents the salient information of the respondents (garment exporting companies) in Indonesia. It has been found that about 81 percent of the respondents are from the top management/CEOs. This finding has reflected the purpose to 
Shihab \& Jain-The Preparedness of the Indonesian Garment Exporters in...

Table 1. Exporter Respondents' Characteristics: Indonesia

Percentage $(\%)$

Job Titles

Director/CEO etc. $\quad 81.3$

Marketing Manager $\quad 10.7$

Others 8.0

Experience in Exports of Garments

$\begin{array}{lr}<5 \text { years } & 6.5 \\ 5-10 \text { years } & 61.1 \\ 10-15 \text { years } & 22.2 \\ >15 \text { years } & 10.2\end{array}$

Average Annual Exports

In value terms

< US\$10 mn $\quad 51.4$

US\$ 10 - $20 \mathrm{mn} \quad 42.2$

US\$ 20 - $50 \mathrm{mn} \quad 5.5$

> US\$50 mn $\quad 0.9$

In volume terms (units)
$\quad<0.50 \mathrm{mn}$

$0.50-1 \mathrm{mn} \quad 40.4$

$1-2 \mathrm{mn} \quad 7.3$

$>2 \mathrm{mn} \quad 4.6$

E-Mail Availability

Specified $\quad 84.9$

Not specified $\quad 15.1$

Web-Site Availability

Specified $\quad 7.6$

Not specified $\quad 92.4$

Type of Organization

Manufacturer $\quad 83.3$

$\begin{array}{ll}\text { Merchant } & 16.7\end{array}$

Geographic Location

Greater Jakarta $\quad 59.3$

West Jawa $\quad 14.2$

East Jawa $\quad 4.4$

Central Jawa $\quad 9.8$

$\begin{array}{lr}\text { Others } & 12.4\end{array}$


Gadjah Mada International Journal of Business, September 2004, Vol. 6, No. 3

Table 2. Percentage Distribution of the Indonesian Sample Exporters by Their Export Trend to Destination Markets

\begin{tabular}{|c|c|c|c|c|c|c|c|}
\hline \multirow{3}{*}{$\begin{array}{l}\text { Destination } \\
\text { Country }\end{array}$} & \multirow{3}{*}{ 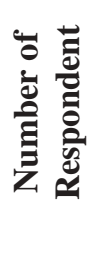 } & \multicolumn{5}{|c|}{ Export Trend } & \multirow[b]{3}{*}{ Total } \\
\hline & & \multicolumn{2}{|c|}{ Export Increasing } & \multirow{2}{*}{$\begin{array}{c}\text { Almost } \\
\text { Stagnant }\end{array}$} & \multicolumn{2}{|c|}{ Export Decreasing } & \\
\hline & & Rapidly & Slowly & & Rapidly & Slowly & \\
\hline USA & 95 & 18.9 & 56.8 & 20.0 & - & 4.2 & 100.0 \\
\hline Canada & 50 & 6.0 & 54.0 & 30.0 & 2.0 & 8.0 & 100.0 \\
\hline Japan & 31 & 22.6 & 35.5 & 19.4 & 16.1 & 6.5 & 100.0 \\
\hline Australia & 20 & 20.0 & 30.0 & 20.0 & 10.0 & 20.0 & 100.0 \\
\hline UAE & 31 & 16.1 & 48.4 & 25.8 & 6.5 & 3.2 & 100.0 \\
\hline EU Total & 36 & 16.7 & 36.1 & 38.9 & 5.6 & 2.8 & 100.0 \\
\hline
\end{tabular}

whom the questionnaires have been sent. In addition, it shows the appreciation of the top management towards the purpose of the research. About 61 percent of the respondent companies has been in garment exports for 5 to 10 years. This finding indicates that most exporting companies have been export business from the time the MFA phase-out started. Further, it has been found that majority of the respondents (51.4 percent) have had the average annual exports of less than US\$0 million and 42.2 percent of US\$10 million to US\$20 million. About 85 percent of the respondents have specified the Internet accessibility and e-mail usage. It shows that exporting companies are prepared for the future needs to reduce the paper work as required by importers. However, as to the website availability, less than 10 percent of the respondents have had the affirmative responses indicating their less perceived need for it.

From this sample, basically there are two types of garment exporters: "Manufacturer-Exporters" and "Merchant-Ex- porters." Manufacturer-exporters are those who own manufacturing facility to produce the garments, whereas merchant-exporters are those who get packed shipments or garments made from fabrication units for exports. Some of the merchantexporters provide sampling facilities also (Koshy 1995).

It has been found that almost 84 percent of the respondents are from manufacturer-exporters and remaining from merchant-exporters. Higher percentage from manufacturer-exporters has indicated the sincerity of doing business in this sector. Majority of the sample are located in Greater Jakarta, which includes JABOTABEK (Jakarta, Bogor, Tangerang and Bekasi), and West Java. The concentration of the geographical location might be due to the facilities provided by the government to boost the exports of this sector. In the sample, 59.3 percent of the respondents are from Greater Jakarta, followed by West Java (14.2 percent), Central Java ( 9.8 percent), East Java (4.4 percent) and others (12.4 percent). 
Shihab \& Jain-The Preparedness of the Indonesian Garment Exporters in...

As per export destination markets, it has been found that majority of the exporters are still inclined to export to the quota markets such as USA, Canada and EU. This indicates that the diversification of the destination market has been less among the Indonesian exporters. Their exports have increased slowly in most destination markets except the EU where exports have remained stagnant during the last five years (Table 2).

\section{Perceptions of the Exporters on Emerging Issues}

Questions under this section have been used in an effort to understand the perceptions of the Indonesian sample respondents on the emerging issues. 27 variables have been set under this section. In order to understand the existing issues faced by the Indonesian garment exporters, the respondents were asked to evaluate the 27 variables on the basis of their importance. Using Varimax Rotation, these variables were then factorized to determine the salient factors underlying the Indonesian garment exporters' perceptions on the emerging issues. The results of the factor analysis are presented in Table 3. Following Hair et al. (1987: 237), the sample size of 115 is considered sufficient under this study. Only factor loadings of more than 0.50 were retained in this analysis. Twenty five variables were found to be statistically significant. This finding indicates that the emerging issues have been realized by the exporters. Sampling adequacy was also judged by using KMO value. Following Kim and Mueller (1978) in Black and Porter (1995), the KMO value of 0.827 in this study is considered sufficient. Only those factors with an Eigen value greater than 1 are retained.

Seven factors have emerged from this rotation with 74 percent of the total variance explained. These factors were named accordingly on the subjective basis. Factor 1 referred to "time" and therefore was named as "time value related." Other factors have also been named in the similar manner. Thus, factor 2 has been named as "environmental and social compliance related," factor 3 has been named as "labor productivity related." Factors 4, 5, 6 and 7 are named as "IT and automation related," "value addition related," "infrastructure related," and "logistic/channel related" respectively.

The value of alpha was used in this study to indicate the relative reliability of each factor as a scale (Black and Porter 1995). The test of the correlation among the variables loading on the individual factor suggests a high degree of reliability. As seen in Table 3, the Cronbach alpha Coefficients of the first five factors are $0.903,0.846,0.874,0.894$ and 0.742 respectively surpassing the level of 0.70 recommended by Nunnally (1978) for the acceptance level of reliability. The sixth and seventh components, though below the acceptance level have been considered in this study due to their importance.

To understand the underlying relationships between the factors, Pearson Correlation Coefficients have been computed. The results are shown in Table 4. This analysis shows that all factors are correlated, most of them positively and a few negatively and at different significance level. 
Gadjah Mada International Journal of Business, September 2004, Vol. 6, No. 3

Table 3. Construct Measurement Assessment of the Emerging Issues: Indonesia

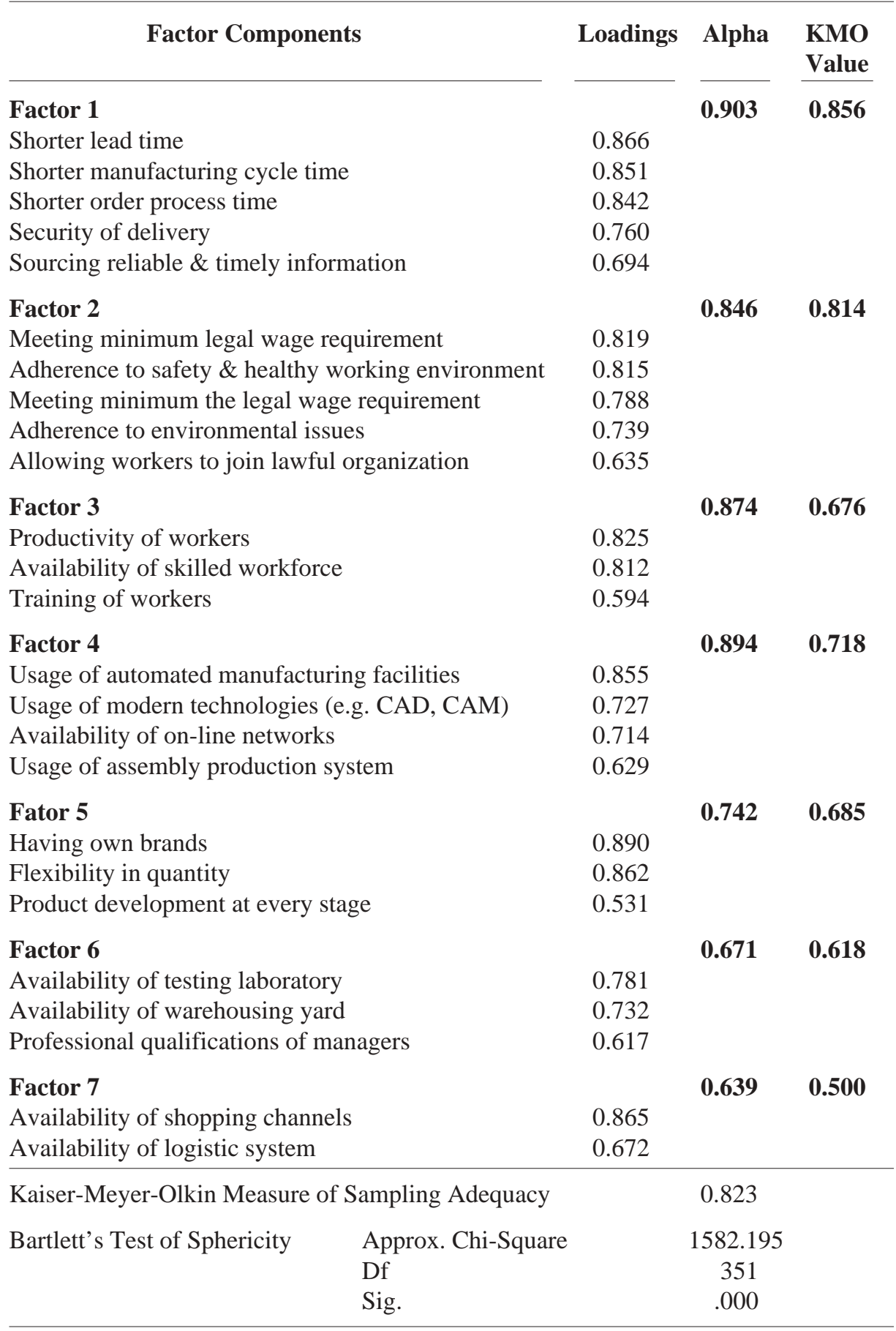

392 
Shihab \& Jain-The Preparedness of the Indonesian Garment Exporters in...

Table 4. Correlation Matrix for the Variables of Interest

\begin{tabular}{|c|c|c|c|c|c|c|c|c|c|}
\hline & Mean & Std. Dev. & $\begin{array}{c}\text { Factor } \\
1\end{array}$ & $\begin{array}{c}\text { Factor } \\
2\end{array}$ & $\begin{array}{c}\text { Factor } \\
\mathbf{3}\end{array}$ & $\begin{array}{c}\text { Factor } \\
4\end{array}$ & $\begin{array}{c}\text { Factor } \\
5\end{array}$ & $\begin{array}{c}\text { Factor } \\
6\end{array}$ & $\begin{array}{c}\text { Factor } \\
7\end{array}$ \\
\hline Factor 1 & 3.688 & 0.1069 & & -0.814 & -0.179 & -0.853 & -0.245 & 0.740 & 0.594 \\
\hline Factor 2 & $\cdot 3.378$ & 0.2321 & -0.814 & & 0.716 & $0.966 \mathrm{a}$ & 0.746 & 0.584 & 0.353 \\
\hline Factor 3 & 3.233 & 2.0577 & -0.179 & 0.716 & & 0.619 & $0.976 \mathrm{a}$ & $0.973 \mathrm{~b}$ & 0.615 \\
\hline Factor 4 & 3.720 & 1.3969 & -0.853 & $0.966 \mathrm{a}$ & 0.619 & & 0.618 & 0.399 & -0.473 \\
\hline Factor 5 & 3.010 & 1.6780 & -0.245 & 0.746 & $0.976 \mathrm{a}$ & 0.618 & & $0.975 \mathrm{~b}$ & 0.484 \\
\hline Factor 6 & 4.030 & 1.7937 & 0.740 & 0.584 & $0.973 \mathrm{~b}$ & 0.399 & $0.975 \mathrm{~b}$ & & 0.419 \\
\hline Factor 7 & 3.055 & 1.7751 & 0.594 & 0.353 & 0.615 & -0.473 & 0.484 & 0.419 & \\
\hline
\end{tabular}

Pearson Correlation a) Correlation is significant at the 0.01 level (2-talied).

b) Correlation is significant at the 0.05 level (2-tailed).

\section{Factors of Competitiveness}

This part of the questionnaire has invited the opinion of the respondents on the level of strength of Indonesia's garments industry as compared to major competing countries. Under this section, 31 questions were set which were grouped into 6 main factors, namely "labor related factor," "infrastructure related factor," "laws related factor," "raw materials related factor," "technology/manufacturing related factor" and "other related factors." Respondents have been asked to rate the level of strength of Indonesia on the variables/items of competitiveness for garment exports on the five-point scale starting from extremely low (1) to extremely high (5). The mean value of each variable is tabulated using SPSS package. The discussion of each factor follows:

\section{Labor Related Factor}

Table 5 depicts the mean value of the responses of labor related factor on five variables. Findings indicate some variables have been perceived competitively stronger by the garment exporters. Labor cost has had the highest mean value of 3.84. This finding clearly implies that labor cost is a major competitive factor for Indonesian garments industry as compared to other competing countries. This is in line with the finding made by Werner International Management Consultants (1998) that Indonesia was one of the lowest labor cost country as compared to other major competing countries. It is observed that "availability of skilled workers" and "workers understanding and ability to implement technical instructions" have similar mean value of 3.04 which is slightly below the average. The mean value of "availability of skilled workers while executing big orders" and "workers' discipline and sincerity towards the job" are 2.97 and 2.72 respectively which indirectly suggests that Indonesia's strength has been perceived comparatively low as compared to some other competing countries. However, the overall indicates that the level of strength is at an average. 
Gadjah Mada International Journal of Business, September 2004, Vol. 6, No. 3

Table 5. Indonesia's Level of Strength on Labor Related Factor of Competitiveness

\begin{tabular}{|c|c|}
\hline \multirow[b]{2}{*}{ Variables } & Level of Strength \\
\hline & $\begin{array}{c}\text { Mean } \\
\text { (scale: } 1 \text { to 5) }\end{array}$ \\
\hline Labor Cost & 3.84 \\
\hline Availability of skilled workers & 3.04 \\
\hline $\begin{array}{l}\text { Workers' understanding and ability to implement technical } \\
\text { instructions }\end{array}$ & 3.04 \\
\hline Availability of skilled workers while executing big orders & 2.97 \\
\hline Workers' discipline and sincerity towards the job & 2.72 \\
\hline Overall Average & 3.12 \\
\hline \multicolumn{2}{|l|}{ Variables are in rank order of mean score } \\
\hline & Level of Strength \\
\hline Variables & $\begin{array}{c}\text { Mean } \\
\text { (scale: } 1 \text { to 5) }\end{array}$ \\
\hline Availability of air/sea ports and related logistics & 3.47 \\
\hline Availability of modern telecom infrastructure & 3.26 \\
\hline Availability of power supply & 3.20 \\
\hline Availability of own captive power supply & 3.12 \\
\hline Availability of institutional finance for garment sector & 2.73 \\
\hline Availability of design schools \& specialized institutes & 2.13 \\
\hline Cost of Capital (finances) & 1.95 \\
\hline Overall average & 2.84 \\
\hline
\end{tabular}

Variables are in rank order of mean score

\section{Infrastructure Related Factor}

Seven variables on infrastructure related factor have been listed. The respondents have rated the level of Indonesia's strength on this infrastructure related factor. Table 6 depicts that "availability of air/sea ports and related logistics" has the highest mean value of 3.47 followed by "availability of modern telecom infrastructure" (3.26) and "availability of power supply" (3.20) and can therefore be considered as positive points for Indonesia. 
Shihab \& Jain-The Preparedness of the Indonesian Garment Exporters in...

Table 7. Indonesia's Level of Strength on Business Laws Related Factor of Competitiveness

\begin{tabular}{|c|c|}
\hline & Level of Strength \\
\hline Variables & $\begin{array}{c}\text { Mean } \\
\text { (scale: } 1 \text { to 5) }\end{array}$ \\
\hline User-friendly export-import policies and procedures & 2.87 \\
\hline Simplicity of laws relating to customs/excise duty & 2.61 \\
\hline Nature of export incentives & 2.15 \\
\hline Overall average & 2.54 \\
\hline
\end{tabular}

Variables are in rank order of mean score

However, cost of capital has the lowest mean value that indicates the least competitive factor for this country. This is in line with the interview with some exporters in Jakarta who have indicated that garment exporters have been dissatisfied due to the high interest rates in the country, although getting the funds has not been a major problem.

Further, the "availability of design schools and specialized institutes" has been considered low despite the availability of institutes collaborating with international fashion design schools. This low mean value is in line with the researcher's observation and discussions with some designers during the survey. According to them, the design and fashion institutes available in the country have been managed by private institutes and provide only short training courses at high fees and are mainly located in Jakarta. Thus, it seems the government pays little attention on establishing centers for design and fashion technology at national level as happens in many other countries and these institutes seem to be meant for high-income people.

\section{Business Laws Related Factor}

Respondents were asked to indicate Indonesia's level of strength about business laws related factor on five point scale. The mean value is shown in Table 7. It has been found that all variables got an average score of less than 3.00. This indicates that Indonesia has been perceived less competitive as compared to some other competing countries. This finding might be due to complex policy and procedures. In line with the researcher's observations during the interviews that the respondents implicitly stated the illegal levies, so many "tables" to be passed through etc. are the major concerns of the garment exporters because these in turn increase the costs. It has also been felt by the exporters that the government policy framework such as imports, exports, tariff have been changing frequently.

\section{Raw Material Related Factor}

Table 8 depicts the mean value of the responses on raw material related factor. Four variables are set under this factor. The results are placed in declining value of 
Gadjah Mada International Journal of Business, September 2004, Vol. 6, No. 3

Table 8. Indonesia's Level of Strength on Raw Material Related Factor of Competitiveness

\begin{tabular}{lcc}
\hline \multicolumn{1}{c}{ Variables } & \begin{tabular}{c} 
Level of Strength \\
\cline { 3 - 3 }
\end{tabular} & $\begin{array}{c}\text { Mean } \\
\text { (scale: 1 to 5) }\end{array}$ \\
\cline { 1 - 1 } Availability of desired quantity of fabrics through imports & & 3.22 \\
Availability of desired types of quality fabrics domestically & & 3.00 \\
Availability of required quantity of desired fabrics domestically & 2.86 \\
Timely availability of trims and accessories & & 2.76 \\
Overall average & 2.98
\end{tabular}

Variables are in rank order of mean score

mean. It is interesting to note that of the four variables, "availability of desired quantity of fabrics through imports" has the highest mean value of 3.22 and this is contradicted to the common image of Indonesia as producer of quality fabrics.

This response seems to have been due to the government policy, which has encouraged the imports of fabrics for export purpose with zero import tax. On the contrary, the garment producers who used the local fabrics are taxed. In interviews with several members of API, it has been found that most imported fabrics from Singapore and other countries have been basically from Indonesia. Such problems exist because garment exporters want to get exemption from the taxes. This may explain the reason of the high score on this variable. The mean value of "availability of required quantity of desired fabrics domestically" has been low at 2.86 indicating the weak level of Indonesia's competitiveness as compared to major competing countries.

\section{Technology/Manufacturing Related Factor}

Technology is not only a buzzword but is a must in today's garments industry. Buyers from developed countries put pressures on the garment exporters to use modern technology. The mean value of responses of each variable under this factor is presented in Table 9. It has been found that the mean value for "availability of automated manufacturing facility" and "availability of modern technologies (such as CAD, CAM)" are 3.23 and 3.20 respectively indicating that the respondents are on the opinion that Indonesia remains competitively high on these variables. However, the mean value of "availability of online networks" and "availability of manufacturing facility under one roof" are 2.99 and 2.58 respectively indicating that Indonesia' level of strength is average. However, the overall average is 2.99 . 
Shihab \& Jain-The Preparedness of the Indonesian Garment Exporters in...

Table 9. Indonesia's Level of Strength on Technology/Manufacturing Factor of Competitiveness

\begin{tabular}{lcc}
\hline Variables & $\begin{array}{c}\text { Level of Strength } \\
\end{array}$ & $\begin{array}{c}\text { Mean } \\
\text { (scale: 1 to 5) }\end{array}$ \\
\cline { 1 - 1 } Availability of automated manufacturing facility & & 3.23 \\
Availability of modern technologies (such as CAD, CAM) & & 3.20 \\
Availability on on-line networks & 2.99 \\
Availability of manufacturing facility under one roof & 2.58 \\
Overall Average & 2.99 \\
\hline
\end{tabular}

Variables are in rank order of mean score

Table 10. Indonesia's Level of Strength on Other Related Factor of Competitiveness

\begin{tabular}{|c|c|}
\hline & Level of Strength \\
\hline Variables & $\begin{array}{c}\text { Mean } \\
\text { (scale: } 1 \text { to 5) }\end{array}$ \\
\hline Ability to follow fashion trends & 3.19 \\
\hline $\begin{array}{l}\text { Access to buying house, agents \& distribution channels } \\
\text { in foreign markets }\end{array}$ & 3.02 \\
\hline Readiness towards non-tariff barriers & 3.02 \\
\hline Domestic demand of quality fashion garments & 2.89 \\
\hline Availability of competent designers & 2.55 \\
\hline Government supports and incentives & 2.32 \\
\hline Image of "Made in Indonesia" in international markets & 2.13 \\
\hline Overall Average & 2.74 \\
\hline
\end{tabular}

Variables are in rank order of mean score

\section{Other Related Factor}

The respondents were asked to rate the level strength of Indonesia on the other related factor on the five-point scale. Mean value of each variable is presented in Table 10. Variables such as "ability to follow fashion trends," "access to buying houses in foreign markets" and "readiness towards non-tariff barriers" have the mean value of 3.19, 3.02 and 3.02 respectively indicating that Indonesia is competitively strong as compared to major competing countries. Other variables such as "government initiatives and supports" have fallen at 2.32 indicating the concerns of the government have been perceived low. "Image of 'made in Indonesia' in international markets" achieved the lowest mean value at 2.13. From this finding it can be inferred that Indonesia may only be the 
jobber, if there is no effort to improve the image.

\section{Strategic Choices}

The following analysis will discuss the strategies that have been adopted by the Indonesian garment exporters in their own companies ("own strategies") during the MFA phase-out period (1995 onwards). As seen in the sample characteristics that most of the respondents had the experience of more than 5 years and thus supported the analysis of this part. This analysis is also aimed at understanding the garment exporters' perceptions on which strategic choices other companies in the country have adopted. The choices were "slowly adopting" (1) "moderately adopting" (2), and "actively adopting" (3). Twenty seven variables of strategic choices under this section have been grouped into seven namely General Strategy (GS), Market Focus Strategy (MF), Value Addition Oriented Strategy (VA), System/Quality Technology (SQ), Developing Network Strategy (DN), Compliance and People Development Strategy (CP), and Diversifying into Retailing (DR). The mean value against each item has been tabulated in Table 11. The overall strategic choices and the discussion on each item follow.

\section{General Strategy}

The general strategy has been coded as GS1 for applying cost reduction strategy, GS2 for applying time reduction strategy, and GS3 for keeping constant touch with designers overseas. It has been found that the mean value of GS1 and GS2 are 2.75 and 2.56 respectively, which indicates active adoption of these strategies. The findings also indicate that the respondents have keen interest on the cost reduction and the quick response. The GS3 has the mean value of 1.19 indicating slow adoption on this strategy. The lower mean value of G3 might indicate that the respondents have had less interest in moving up their strategy to a higherend market through fashions. The exporters are not willing to move up to fashion due to its tiny market and many good players such as Italy and France have come up in this arena. Respondents have perceived other companies have also had active adoption on GS1 and GS2 and slow adoption on GS3.

\section{Market Focus Strategy}

There are four strategic choices which are coded as MF1 for capturing high end markets, MF2 for capturing low end markets, MF3 for focusing on large markets like USA and EU, and MF4 for focusing on non-quota markets. Under "own" company strategy, it has been found that MF2 and MF3 have had the mean value of 2.57 and 2.52 respectively indicating active adoption on these strategies. Higher average of MF3 is in line with the general condition that almost 80 percent of the respondents have gone to quota markets such as USA and EU.

However, capturing higher end markets (MF1) has not been attractive to the exporters. This might have been due to the intense competition from countries, which are advanced in this area. The respondents have also perceived "other" garment exporting companies in the country in general have similar strategies. It cannot be denied that some companies have adopted MF1 and MF4 actively. But in general respondents have perceived that other competitors have moderately adopted these strategies.

\section{Value Addition Oriented Strategy}

Under this strategy, there are four variables, which are coded as VA1 for developing own brands for overseas mar- 
Shihab \& Jain-The Preparedness of the Indonesian Garment Exporters in...

Table 11. Strategic Choices Adopted by Exporting Companies

\begin{tabular}{|c|c|c|c|}
\hline \multirow{2}{*}{\multicolumn{2}{|c|}{ Strategic Choice }} & \multicolumn{2}{|c|}{ Score Scale: 1 to 3} \\
\hline & & $\begin{array}{l}\text { Own } \\
\text { Company } \\
\text { Mean }\end{array}$ & $\begin{array}{c}\text { Other } \\
\text { Competitors } \\
\text { Mean }\end{array}$ \\
\hline \multicolumn{4}{|c|}{ General Strategy (GS) } \\
\hline GS1 & Applying cost reduction strategy & 2.75 & 2.40 \\
\hline GS2 & Applying time reduction strategy & 2.56 & 2.37 \\
\hline GS3 & Having constant touch with designers overseas & 1.19 & 1.20 \\
\hline \multicolumn{4}{|c|}{ Market Focus Strategy (MF) } \\
\hline MF1 & Capturing high end markets & 1.04 & 2.26 \\
\hline MF2 & Capturing low end markets & 2.57 & 2.49 \\
\hline MF3 & Focusing on large markets like USA and EU & 2.52 & 2.42 \\
\hline MF4 & Focusing on Non-quota markets & 1.03 & 2.05 \\
\hline \multicolumn{4}{|c|}{ Value Addition Oriented Strategy (VA) } \\
\hline VA1 & Developing own brands for overseas markets & 1.02 & 1.38 \\
\hline VA2 & Applying product differentiation strategy & 1.39 & 2.01 \\
\hline VA3 & Specializing in particular products & 2.60 & 2.49 \\
\hline VA4 & Applying customization strategy & 1.02 & 1.39 \\
\hline \multicolumn{4}{|c|}{ System/Quality Technology Strategy (SQ) } \\
\hline SQ1 & Developing production base in other countries & 1.01 & 1.16 \\
\hline SQ2 & Adoption of ISO 9000 certification & 2.04 & 2.06 \\
\hline SQ3 & Adoption of ISO 14000 certification & 1.96 & 2.04 \\
\hline SQ4 & Ensuring quality standards at vendor level & 2.16 & 2.02 \\
\hline SQ5 & $\begin{array}{l}\text { Using E-commerce as a part of the plan of } \\
\text { the organization }\end{array}$ & 1.09 & 2.04 \\
\hline SQ6 & Setting up manufacturing facility & 1.65 & 1.92 \\
\hline \multicolumn{4}{|c|}{ Developing Network Strategy (DN) } \\
\hline DN1 & Developing vendor relationship & 2.06 & 2.44 \\
\hline DN2 & Developing relationship with importers overseas & 2.60 & 2.50 \\
\hline DN3 & Setting up joint ventures & 1.28 & 1.59 \\
\hline \multicolumn{4}{|c|}{ Compliance \& Development Strategy $(\mathrm{CP})$} \\
\hline $\mathrm{CP} 1$ & Commitment for compliance issues & 2.50 & 2.53 \\
\hline $\mathrm{CP} 2$ & Developing employees competency & 1.52 & 2.07 \\
\hline $\mathrm{CP} 3$ & Increasing commitment to productivity & 2.44 & 2.54 \\
\hline \multicolumn{4}{|c|}{ Diversifying Into Retailing (DR) } \\
\hline DR1 & Setting up local retail shops & 1.05 & 1.52 \\
\hline DR2 & Promoting local retail markets with own brands & 1.03 & 1.53 \\
\hline DR3 & Setting up overseas retail markets & 1.02 & 1.17 \\
\hline
\end{tabular}


kets, VA2 for applying product differentiation strategy, VA3 for specializing in particular products and VA4 for applying customization strategy. It has been found that VA3 has had the mean value of 2.60 indicating active adoption. Meanwhile, VA1, VA2 and VA4 have had lower mean value indicating slow adoption of these strategies. It is interesting to note that although VA1 may be a useful strategy for the future it has the lowest mean value. It seems that it is not critical for exporters and thus it indicates that exporters are not willing to develop their own brands. During the interviews with some exporters, it was found that the unwillingness of the exporters to have own brands is because it requires a lot of investment and is time consuming. In addition, quota system has killed their possible initiatives in this direction. The slow adoption of VA4 indicates that many garment exporters still do not realize the importance of this emerging strategy. However, the garment exporters have perceived these four strategic choices as "moderately" adopted by other companies in general.

\section{System/Quality Technology Strategy}

The System/Quality Technology Strategy enlists six variables which have been coded as SQ1 for developing production base in other countries, SQ2 for adoption of ISO 9000 certification, SQ3 for adoption of ISO 14000 certification, SQ4 for ensuring quality standards at vendor level, SQ5 for using e-commerce as a part of the plan of the organization, SQ6 for setting up manufacturing facility. SQ1 and SQ5 have been found to have lowest mean value of 1.01 and 1.03 indicating the slow adoption on these strategies. What is appealing is that while many other competing countries have started to 'develop production base in other countries and using e-commerce as a part of the plan of the organization,' Indonesian garment exporters have slowly adopted these strategies. The mean value for SQ2, SQ3, SQ4 and SQ6 are 2.04, 1.96, 2.16 and 1.65 respectively indicating moderate adoption on these strategies. However, the respondents have perceived in general that other competing companies in the country have moderately adopted all the mentioned strategies except SQ1.

\section{Developing Network Strategy}

Three are three aspects of network strategy, which are coded as DN1 for developing vendor relationship, DN2 for developing relationships with importers overseas and DN3 for setting up joint ventures. It has been found that DN2 has the mean value of 2.60 indicating active adoption on this strategy. DN1 has been moderately adopted, whereas DN3 has the lowest mean value of 1.28 indicating slow adoption. Respondents have perceived that some other competing companies in the country have adopted these strategies actively except DN3, which was moderately adopted.

\section{Compliance and People Development Strategy}

There are three aspects of compliance and people development strategy, which are coded as CP1 for commitment for compliance issues, CP2 for developing employees competency and CP3 for increasing commitment to productivity. CP1 and CP3 have been found to be actively adopted by the respondents whereas $\mathrm{CP} 2$ has been moderately adopted. The low mean value of $\mathrm{CP} 2$ indicates the concern on the development of the workers is still low by the exporters. This can be because of the high labor turnover in this industry that exporters feel that such a strategy is 
Shihab \& Jain-The Preparedness of the Indonesian Garment Exporters in...

unnecessary. However, the respondents have perceived that other competing companies in the country adopt these strategies actively except CP2 that was moderately adopted.

\section{Diversifying into Retailing}

There are three strategies relating to diversification into retailing which are coded as DR1 for setting up local retail shops, DR2 for promoting retail markets with own brands and DR3 for setting up overseas retail markets. It has been found that the mean values for DR1, DR2 and DR3 are 1.05, 1.03 and 1.02 respectively indicating slow adoption of these strategies. It can be inferred that manufacturers still rely very much on the retailers to sell their products and thus they are not widely sensitive towards these issues. It is noticeable that except DR3 (to have slow adoption), other companies have been perceived to adopt those strategies moderately. The opening up of factory outlets by some companies in the country is an indication towards these strategies. Great River International, for example, has opened its stall in some Mega Malls to promote its own brands.

\section{Conclusion}

One of the dimensions of the exporters' survey was to understand Indonesian garment exporters' perceptions on the emerging issues that are likely to affect the garments exports of Indonesia. It has been found from the analysis that the exporters in Indonesia have realized the issues that have emerged in the WTO regime. This has become evident from the results of the factor analysis. Using varimax rotation, seven factors have emerged from the sur- vey in Indonesia. Another dimension of the survey was to seek the perceptions of the exporters on the level of competitiveness of Indonesia as compared to major competing countries. The overall perceptions of exporters indicate Indonesia is relatively less competitive than other competing countries.

Another important dimension was to analyze the strategies adopted by the companies. The strategies like "capturing low end markets," "focusing on large market like USA and EU," and "specializing in particular products" have been actively adopted by the exporters in Indonesia. On the other hand, the adoption of the strategic choices such as "diversifying into retailing," "developing own brands," "developing production base in other countries," and "using e-commerce as a part of the plan of the organization" has been comparatively slow. Since the future competition is very tough starting from the issues of environment and social compliance, adoption of technology etc., garment manufacturers in Indonesia need to work with efficiency to achieve good price and be competitive. The garment manufacturers/exporters in Indonesia need to have thoroughness and seriousness in tackling those issues in order to successfully survive in the future. They need to rethink their strategies, work with vision and commitment and so that they can take steps to improve the image of the country in general. The key successful factors seem to be based on how the issues related to social compliance, time value (quick response), value addition, connectivity (networking), automation, HR management (productivity) collaboration are managed efficiently and effectively. 
Gadjah Mada International Journal of Business, September 2004, Vol. 6, No. 3

\section{References}

Anson, R. 2001. Speed, connectivity and value-creating intangibles: The new rules of the international apparel sourcing business. Textile Outlook International (November).

Bhattacharya, H. P. 1999. MFA: Possible implications of dismantling for Indian exports. Asian Textile Journal (October).

Birnbaum, D. 2001. The coming garment massacre. Canadian Apparel Magazine (November-December).

Black, S., and L. J. Porter. 1995. An empirical model for total quality management. Total Quality Management 6 (2).

Brookes, R. 1988. The New Marketing. England: Gower Publishing Company.

Bull, A., M. Pitt, and J. Szarka. 1993. Entrepreneurial Textile Communities: A Comparative Study of Small Textile and Clothing Firms. London: Chapman and Hall.

Chandra, P. 1999. Competing through capabilities: Strategies for global competitiveness of Indian textile industry. EPW Review of Industry Management (February 27-March $5)$.

Chintakayada, P. K. 1999. Info-Com revolution and its impact on India textile industry. Clothesline (July-August).

Clothesline. 2001. Sweatshop and Labor Compliances: Current American Situation (June).

Das, A. 2000. IT: The new rules of the game and why you should know them. Apparel Fortnightly (January 1-15).

Dawson, O. L. and J. S. Kang. 2001. Occupational knowledge utilities in international business and economics. Journal of International Business and Economic (Fall).

Debroy, B. 1996. Beyond the Uruguay Round: The Indian Perspective on GATT. New Delhi, India: Sage Publication.

Dennison C. 1995. Textiles and clothing in Indonesia. Textile Outlook International (May).

Dickerson, K. G. 1993. Textile and apparel imports: The consumer choice. www.muextension.missouri.edu.

Diesback, D. De. 2000. Understanding the ultimate customer —European-American. In Winning Ways for the Future Apparel Business edited by Vinod Shanbhag, and A. K. G. Nair. New Delhi, India: Global Business Press

Djafri, C. 1999. Perkembangan TPT Indonesia (development of textile and textile products in Indonesia). Paper Presented at Yayasan Indotex, API (August). Jakarta.

Ellis, D. 2000. Outlook for decade: Optimism. Textile World (January).

Fashion and Beyond. 2000. IT in India: Textile and Clothing Industry and Trade (January). 
Shihab \& Jain-The Preparedness of the Indonesian Garment Exporters in...

Fernando, L. 2000. Competition after 2005. Garment Times (5) (May).

Fralix, M. T. 2001. From mass production to mass customization. Journal of Textile and Apparel Technology and Management (1) (2) (Winter).

Gapalsamy, N. 1998. GATTIWTO TRIPS, TRIMS and Trade in Service. New Delhi, India: Wheeler Publishing.

Hair, J. F, Jr., R. E. Anderson, and R. L. Tatham. 1987. Multivariate Data Analysis with Reading ( $2^{\text {nd }}$ ed.). USA: Macmillan.

IIFT. 1997. Export and management capabilities of the Indian garments industry. Paper prepared for the Textile Committee Office. New Delhi.

Jain, A. 2000. The role of the merchandiser. In Winning Ways for the Future Apparel Business edited by Vinod S., and A. K. G. Nair. New Delhi, India: Global Business Press.

Kathua, B. C. 2000. Problems and prospects Indian textile industry in the new millennium. Asian Textile Journal (January).

Katti, V., and S. Sen. 2000. MFA phasing-out and Indian textiles industry. Foreign Trade Review (Oct-March).

Khanna, S. R. 1991. International Trade in Textiles: MFA Quotas and A Developing exporting Country. New Delhi: Sage Publication.

Kilduff, P. 2000. Evolving strategies, structures and relationships in complex and turbulent business environments: The textiles and apparel industries of the new millennium. Journal of Textile and Apparel Technology and Management 1 (Sept.).

Kini, M. C. 2000. Quality of service and quality of communication. In Winning Ways for the Future Apparel Business edited by Vinod S., and A.K.G. Nair. New Delhi: Global Business Press.

Koshy, D. O., and S. K. Jain. 1994. MFA phase-out and competitiveness of Indian garment exports. The Indian Textile Journal (8).

Koshy, D. O. 1995. A study of export marketing of Indian readymade garments: Towards a strategic for competitive advantage. Ph.D. Thesis. Delhi, India: Indian Institute of Technology Delhi.

Koshy, D. O. 1997. Garment Exports: Winning Strategies. New Delhi, India: PrenticeHall of India Private Ltd.

Koshy, D. O. 1998. Apparel exports: Toward managing turbulence. The Indian Textile Journal (November).

Koshy, D. O. 1999. Towards qualitative advantage in garment exports. Apparel Online (May 16-31).

KSA-Technopak. 1999. India subcontinent - textiles and clothing: Post 2004 scenario. Fashion and Beyond (November). 
Gadjah Mada International Journal of Business, September 2004, Vol. 6, No. 3

Mathew, S. 2000. The apparel business: IT to dictate terms. The Indian Textile Journal (April).

Mehta, P. S. 1997. The apparel busniness - Who wins, who loses and why. Briefing Paper (May No. 5).

Moon, K.L., C.S. Leung, M. T. Chang, and K. W. Yeung. 1997. Strategic responses by Hong Kong textile and clothing firms toward the MFA. Journal of Textile Institute (88) Part 2:1.

Muchsin. 1998. A Study of Indonesian garment exports. Minor Project.Delhi Indian Institute of Technology.

Nunnally, Jum, C. 1978. Psychometric Theory. USA: McGraw Hill Book Company. USA.

Panthaki, M. K. 2000a. Cosmetic changes, but remnants of irritants to go. The Indian Textile Journal (January).

Panthaki, M. K. 2000b. Shifting pattern in garment exports: Some revelations. The India Textile Journal (April).

Panthaki, M. K. 2001. Garment QRs: The ground realities. The Indian Textile Journal (May).

Prada, G. M. 1998. Implications in Europe market: MFA phase-out agreement. Clothesline (January).

Singletary, E. P., and S. C. Winchester Jr. 1998. Beyond mass production: Competitive transformation trends in the US textile Industry. Journal of Textile Institute (89) Part 2: 1 .

Stiedtmann, C. 2000. Global economics and the apparel industry: Sharpening your consumer centric edge. Apparel Industry Magazine (March).

Sung, V. 2000. Meeting the new order challenge. Textile Asia (June).

Tait, N. 2001a. Mass customization: The new trend - But Why? Clothesline (January).

Tait, N. 2001b. WRAP up ethical sourcing into one package. Clothesline (November).

Textile Asia, 2000. Regional Notes: Learn to Supply (ed. June).

Yung, Y. 1999. China's Textile and Clothing Exports: Changing International Comparative Advantage and Its Policy Implications. Australian National University (http// ncdsnet.anu.edu.au).

Werner International Management Consultants. 1998. Hourly Labor Cost in The Apparel Industry.

www.bharattextile.com 